\title{
Hydrogeological Survey for Interpretation of Damaging Process in Ancient Grave of Naqsh-e-Rostam, Iran
}

\author{
Azadeh Ghobadi ${ }^{1}$, Mohammadamin Emami ${ }^{1,2}$ and Hesam Aslani ${ }^{1}$ \\ 1. Department of Conservation \& Archaeology, Art University of Isfahan, Isfahan 1744, Iran \\ 2. Department of Building Material Chemistry, University Siegen, Siegen 57068, Germany
}

\begin{abstract}
Naqsh-e-Rostam is known as an ancient periphery which is located in northwest of Persepolis in Fars Province, Iran. The oldest relief at Naqsh-e-Rostam is severely damaged and dates to 1,200 B.C.. There is a rock relief thought to be elimate, originally. Four tombs belonging to Achaemenid kings are carved out of the rock face and seven oversized rock reliefs at Naqsh-e-Rostam depict the monarchs of the Sassanid Period. These works are located in orographic mountains which are exposed to the interaction with their surrounding environment. Therefore, existing deterioration as well as erosion process is mainly observed due to climatically conditions and geo-environmental factors which have caused such challenges. Transverse and micro cracks are most kinds of damages that will result in erosion in whole of these works. The focal sources which cause ground cracks have been studied with hydro geological survey. Actually considering the storage volume changing and the calculation of hydrological budget for aquifer, this conclusion drown that the ground crack in this site is the direct result of land subsidence resulting from ground water extraction.
\end{abstract}

Key words: Rock reliefs, subsidence, ground water extraction, hydrological budget.

\section{Introduction}

Fars with its special historic and geographic location has always been remarkable for scientific and research centers in Iran and also in the world, there is a history of research which has been carried out there. Marvdasht as a primeval region of Iran with its rich history has been considered by too many archaeologists and Iranian culture lovers. Recorded history of this site is returned to the 5th millenniums B.C. Research proved that this region has been residential till now and it is as old as the known history of Iran [1]. Existing some ancient monuments and evidence of Iran in Marvdasht, made it the cradle of culture and civilization of Iran which is forerunner of the ancient worlds imperial and land of ancient heritage protector. The collection of interesting remained evidences made Marvdasht a very important site which is always considerable.

Corresponding author: Azadeh Ghobadi, Ph.D. candidate, research fields: GIS and cultural heritage deterioration diagnosis. Email: azadeh.ghobadi@yahoo.com.
Historical yard of Naqsh-e-Rostam, as a part of this region is also considered in so many archaeological and historical studies.

Naqsh-e-Rostam is known as an ancient periphery which is located in northwest of Perspolice in Fars (nowadays Shiraz), Iran. The oldest relief at Naqsh-e-Rostam is severely damaged and dates to 1,200 B.C.. There is a rock relief thought to be Elamite, originally. Four tombs belonging to Achaemenid kings are carved out of the rock face and seven oversized rock reliefs at Naqsh-e-Rostam depict the monarchs of the Sassanid Period (Fig. 1).

In Sasanian epoch, Naqsh-e-Rostam site was very important because of its religious and national role [2]. While Ernst Emil Herzfeld and Heidemarie Koch determined its ancientness about 4,000 B.C. (Fig. 2). This historical site which is one of the most unique evidences in Iran, is suffering from some problems like erosion and deep cracks [1, 3]. Currently, several damages threaten this site, which is also considerable on the high reliefs and some on the ground, closed to the reliefs. Beginning of land subsidence in 2008 around 


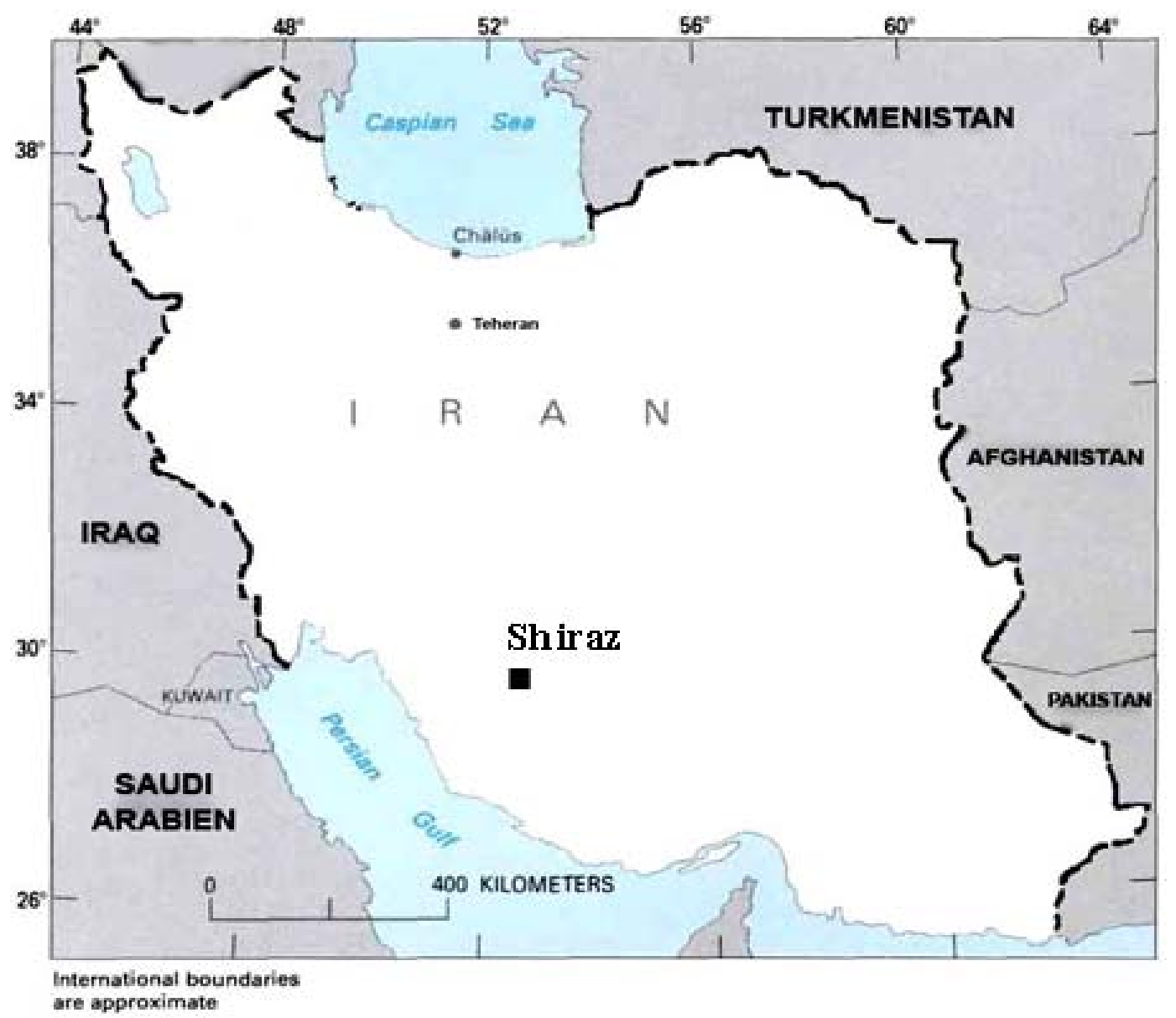

Fig. 1 Map of Iran and the location of Shiraz province.

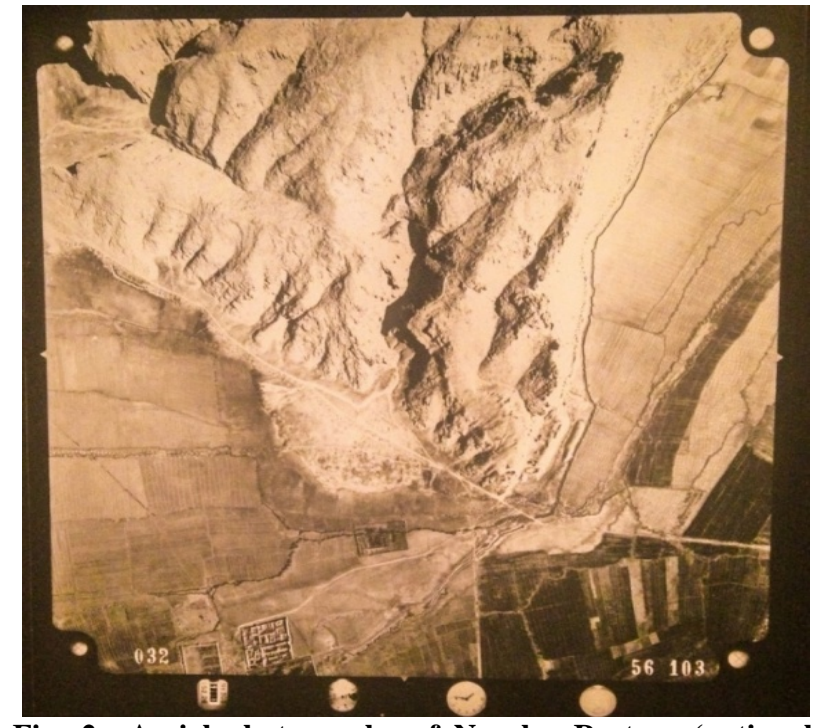

Fig. 2 Aerial photography of Naqsh-e-Rostam (national cartographic center of Iran in 1993).

this site caused serious worries about demolition of the whole monument. This subsidence could have many probable causes. In fact, creation of another crack in 2011 about $5 \mathrm{~m}$ far from Hossein mountain and paralleled with another crack which situated about 20 $\mathrm{m}$ far from it, conducted this case studies to find out the sources of creation and extension of this phenomena. According to the research and analysis done by "Geology Organization and Mineral Discovery" and "National Station of Geological Database of the Country", some tectonic factors, earthquake and Rahmat fault are not the reason for ground crack in this area [4]. Some researchers believe that these cracks could be emerged as a result of over usage of groundwater utilizes, but this hypothesis is just accurate about the joint, because there is still no movement. Groundwater resources charge directly or indirectly from surface water and precipitation $[5,6]$. Therefore, sustainable usage of them means limited 
and reasonable utilization. In the current years in many countries, the discharge of groundwater is more than their charge. This means over-extraction of the water which stored during thousands of years in water-bearing layers of the ground. In this manner, the groundwater level in the area would be decreased diurnally which causes drying of downstream regions, qanats, wells and strings and emerging subsidence phenomenon which causes cracks, cleavage and finally sinkholes.

Subsidence is a national process which is an environmental hazard and it is enforced by human activities. Most of the surface subsidence occurs when some materials like oil or groundwater are exhausted from gaps between the rocks, in fact, subsidence is a phenomenon which caused by extraction industries.

In this case study, groundwater subsidence in the area and its effects on creation of the cracks has been considered (Fig. 3).

Groundwater-related subsidence is the subsidence of land resulting from groundwater extraction, and a major problem in the developing world as major metropolises swell without adequate regulation and enforcement, as well as being a common problem in the developed world. One estimate has $80 \%$ of serious land subsidence problems associated with the excessive extraction of groundwater, making it a growing problem throughout the world [7].

In Mexico, the buildings interact with the settlement, and cause cracking, tilting, and other major damage. In many places, large sinkholes open up, as well as surface cavities [1, 8]. Damage from Hurricane Katrina was exacerbated due to coastal sinking associated with groundwater withdrawal.

In the San Joaquin Valley of the United States, groundwater pumping for crops has gone on for generations. This has resulted in the entire valley sinking an extraordinary amount. Other regions of the world, such as New Orleans and Bangkok are now subject to severe flooding due to subsidence associated with groundwater removal. California's groundwater has been pumped as needed in many areas of the state, often with little regard for the deleterious effects of over pumping [9]. Studies in this area confirm that land subsidence in California is not only a historical occurrence, but also an ongoing problem in many regions and present key examples of significant historical subsidence.
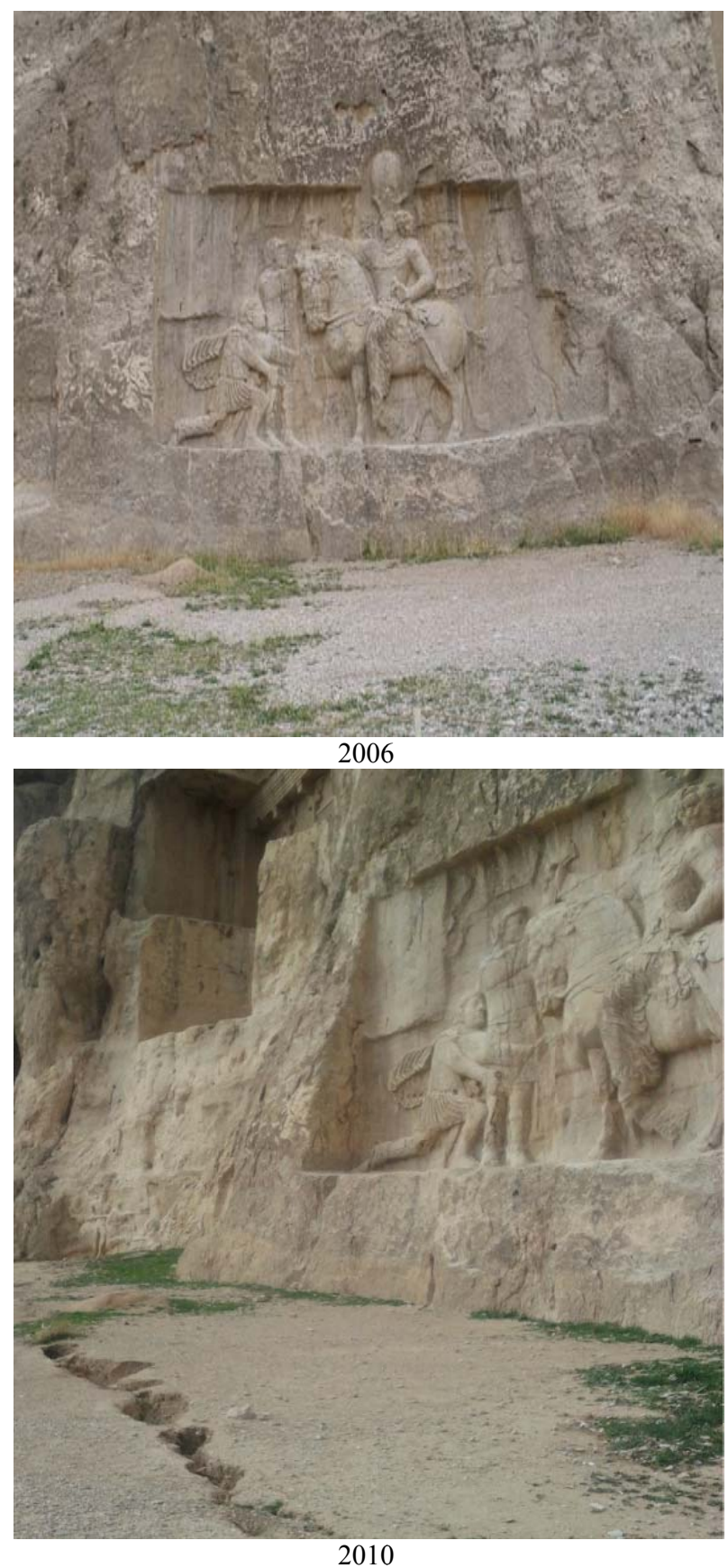

Fig. 3 Ground crack front of Shapur's victory relief (after and before subsidence). 


\section{Methodology}

\subsection{Data Sources}

Groundwater extraction from nearly any aquifer will cause some degree of subsidence as aquifer materials adjust to new stresses. In fact, any change of groundwater levels from any cause, natural or human induced, will move the land surface up or down in response to expansion or compression of aquifer materials.

Regarding the information about stratigraphy and lithology, verification and surveying of several kinds of subsidences are possible like subsidence caused by compaction in accusation with ground resistance, subsidence in association with hydrologic compaction relating to ground material and genre, subsidence caused by decomposition and subsidence resulted in decreasing groundwater level. In this research, subsidence resulted in decreasing groundwater level in Marvdasht area has been considered and estimated. This event caused by cumulative pumping of groundwater and decreasing underground water tables levels. This kind of subsidence generally occurs in a vast area, and geological conditions are important factors in its generation.

In order to compile the necessary information, gathering groundwater resources data have been done by referencing regional water companies and consulting companies which work in the field of basin water resources. These data have been reformed to be analyzed and presented as Geo database.

Land information like geology, geomorphology and hydrology has been gathered and topographical maps with the scale of 1:50,000 have been used to produce geomorphological maps [10]. Geophysical studies in the considered basin have been done by General Geophysics and "Ab-Kave Consulting Engineers" and also by department of energy and currently by "Yekom Consulting Engineers Co." in which overall of 1989 electric cartelization has been done. Till now, in 118 excavated exploration wells (salt-alluvial) and in 130 utilization alluvial wells, the pumping tests have been done to obtain hydrodynamic indices of aquifer (Fig. 4). Among the tested wells, 83 ones were alluvial and 35 ones were limy. Piezometric level is utilized to represent the maps in which groundwater level flow assumed to be basically horizontal, so co-potential levels are vertical $[11,12]$. Preparing these maps, some observation wells have been excavated there till the mentioned water level. Observation wells should be excavated for estimating the groundwater level changes. Surveying these wells based on the water level in that situation and therefore, in the whole aquifer could be used for reaching the information about the water level, groundwater resource (well, strings and qantas), existence of strings, drainage and tectonic factors (fault) which cause local changes in the groundwater level.

\subsection{Estimate Water Budget Components}

The greatest study area is Tashak, Maharlou \& Bakhteghan, Marvdasht-Kharame region basins [10]. The area of Tashak, Maharlou \& Bakhteghan is about $3,971 \mathrm{~km}^{2}$, in which plain area is about $2,452.5 \mathrm{~km}^{2}$ and high lands region is about $1,488.5 \mathrm{~km}^{2}$. This research field includes basin of two important rivers namely: Kor and Sivand. Kor River (after Douroudzan dam in the beginning of plain area), after passing the

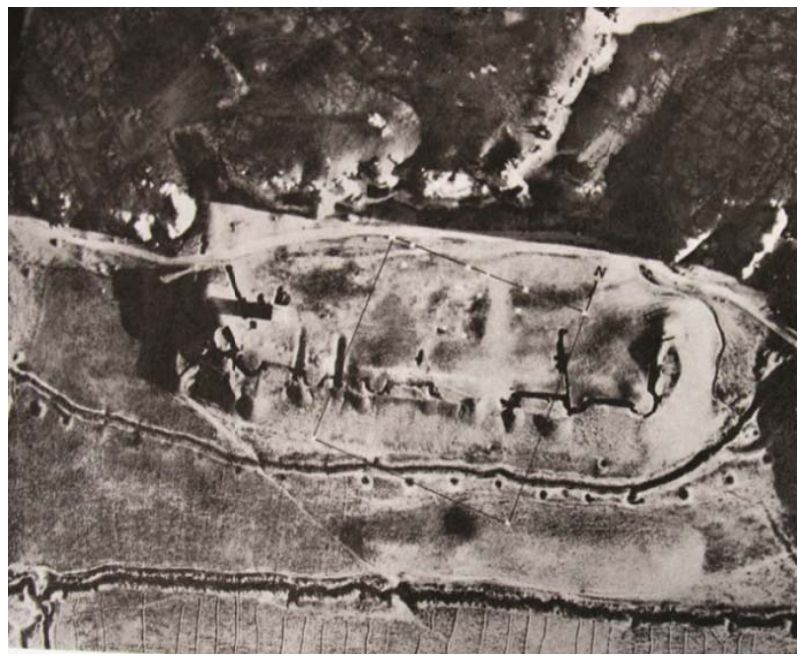

Fig. 4 Aerial photo of Naqsh-e-Rostam and the usage of qantas in cultivation (Shapour Shahbazi in 1357). 
plain and adjunction with Maein minor river, is joined with Sivand River in a place called Polk-e-Khan and in the ending of the study area flow into Bakhtegan River. The greatest transmissivity is in the center of plain and near to confluence of Kor and Sivand rivers which is about $1,000 \mathrm{~m}^{2}$ per day and it could be a result of existence of coarse disunited sediments. In the area between high lands and main plain rivers, also in most of the Kharame plain area considering the granule sediments, the amount of transmissivity is low (roughly $300 \mathrm{~m}^{2}$ per day). Pumping test has been done in seven explorative alluvial wells and 22 low deep utilization wells. The maximum transmissivity index was 1,362 $\mathrm{m}^{2}$ per day, which was recorded in a well with the UTM (universal transverse Mercator coordination) of ( $X=725,800, Y=3,247,300)$.

Regional aquifer is extended from north-west to south-east, situated in the center of basin and feeding from cretaceous limes from north and east (especially Seruk formation in the Bangestan group) and Jahrom Asmari limes from south and west. On the other hand, this area has a good feeding condition. Groundwater resources of this area are included: 7,145 wells with an annual discharge of 797/939 million $\mathrm{m}^{3}$, six aqueducts with an annual discharge of 6/110 million $\mathrm{m}^{3}$ and 35 springs with an annual discharge of 102/353 million $\mathrm{m}^{3}$. Total annual discharge amount of the groundwater resources in this study area is about $906 / 40$ million $\mathrm{m}^{3}$. From the overall groundwater resources consumption, $772 / 3$ million $\mathrm{m}^{3}$ is for agriculture, $28 / 3$ million $\mathrm{m}^{3}$ for drinking water and the rest which is about $1 / 89$ million $\mathrm{m}^{3}$, is consumed for industry. According to the groundwater aligned curves which are drawn with $5 \mathrm{~m}$ intervals, the western and northern high lands are feeding alluvium aquifer and for this reason, the direction of groundwater movement in this plain is from northern and western high lands to south-east (Kharameh and then Bakhtegan Lake). Kor River and its tributary including Maein and Sivand are the permanent rivers of this plain which irrigated the upper parts of the region and served as drainage toward the lower parts.
The same-depth curves of 4-45 $\mathrm{m}$ are covered by the alluvial aquifer of the Marvdasht plain. Groundwater depth in the northern margin of the plain is more than central and southern margin as in the high lands of northern margin of plain (Dashtak-Droodzan), the depth of water reaching $30 \mathrm{~m}$ and in some parts of Maein-Bidgol plain is about $24 \mathrm{~m}$. Moreover, the curves of $45 \mathrm{~m}$ could be seen in the margin of northern high lands of Bal-Lane Tavous plain while in the margin of northern high lands of Marvdasht-Karbal plain, its depth is recorded about $15 \mathrm{~m}$.

Decreasing trend of groundwater depth is continuing toward the central and southern margin in a way that the $3 \mathrm{~m}$ and $5 \mathrm{~m}$ curves covered a vast area of the central and southern parts of Marvdasht plain. Aquifer expansion and its privilege of feeding from limes, reduce the ratio of seasonal and annual changes in the ground water level. In a way that its annual amount is usually lower than $2 \mathrm{~m}$. High water level in the most location of the aquifer is one of the reasons for low ratio of water level fluctuation.

The hydrograph which is an indicator for groundwater changing level, is drown for Marvdasht plain from September 2000 to August 2007 (seven years). According to this hydrograph, groundwater level in the September 2000 was $1,568.44 \mathrm{~m}$ which reached 1,586.15 $\mathrm{m}$ after seven years (August 2007). Considering this hydrograph, groundwater level reduction rate during these seven years was about 0.29 $\mathrm{m}$ and the annual average of reduction was about $4 \mathrm{~cm}$ (Table 1). So Marvdasht aquifer is considered to have a balance state.

The purpose of preparing groundwater budget is to verify the feeding and discharging factors in the project area. The groundwater budget in each area could represent the internal and external groundwater amount of aquifer and thus estimate the aquifer state [13].

\subsection{Budget and Extraction Development}

Evaluation of Groundwater has been done in 765/55 $\mathrm{km}^{2}$ of the Budget area. 
Table 1 Hydrograph, groundwater level in Marvdasht alluvium aquifer (2000-2007).

\begin{tabular}{llllllll}
\hline Water year & $2000-2001$ & $2001-2002$ & $2002-2003$ & $2003-2004$ & $2004-2005$ & $2005-2006$ & $2006-2007$ \\
\hline October & $1,568.44$ & $1,566.1$ & $1,567.04$ & $1,567.96$ & $1,567.92$ & $1,568.36$ & $1,567.91$ \\
November & $1,568.23$ & $1,566.01$ & $1,566.98$ & $1,567.87$ & $1,568.11$ & $1,568.57$ & $1,567.96$ \\
December & $1,568.79$ & $1,565.92$ & $1,566.98$ & $1,567.94$ & $1,568.29$ & $1,568.68$ & $1,568.19$ \\
January & $1,567.91$ & $1,566.38$ & $1,567.39$ & $1,566.11$ & $1,569.83$ & $1,568.77$ & $1,568.37$ \\
February & $1,568.1$ & $1,567.5$ & $1,567.81$ & $1,566.27$ & $1,569.85$ & $1,569.14$ & $1,568.51$ \\
March & $1,568.23$ & $1,567.71$ & $1,568.01$ & $1,569.18$ & $1,569.67$ & $1,569.24$ & $1,568.63$ \\
April & $1,567.73$ & $1,568.32$ & $1,568.05$ & $1,569.54$ & $1,569.92$ & $1,569.35$ & 1,569 \\
May & $1,567.8$ & $1,568.14$ & $1,567.73$ & $1,569.42$ & 1,570 & $1,569.2$ & $1,569.06$ \\
June & $1,567.24$ & $1,567.86$ & $1,567.45$ & $1,569.02$ & $1,569.83$ & $1,568.91$ & $1,568.71$ \\
July & $1,566.94$ & $1,567.92$ & $1,567.78$ & $1,568.67$ & $1,569.84$ & $1,568.61$ & $1,568.75$ \\
August & $1,566.53$ & $1,567.81$ & $1,567.54$ & $1,568.38$ & $1,568.85$ & $1,568.2$ & $1,568.35$ \\
September & $1,566.21$ & $1,567.58$ & $1,567.23$ & $1,568.08$ & $1,568.63$ & $1,568.01$ & $1,568.15$ \\
\hline
\end{tabular}

\subsubsection{The Feeding Factors}

Most important aquifer feeding factors are direct seepage from precipitation, surface flow, underground flow to aquifer and re-seepage of consumed water which could be estimated in the below methods:

(1) Seepage from precipitation:

Total annual volume of precipitation in the plain is about $637 / 8$ million $\mathrm{m}^{3}$, but just a part of this amount could be seepage whose value depends on participation rate and time interval, average topographical slope, plant cover soil permeability, soil average temperature, groundwater and depth [14]. According to the results obtained from climatological, hydrological, geological and hydrogeological study and also field surveying about $43 \%$ of annual rain could seepage to alluvial aquifer which is equal to $273 / 41$ million $\mathrm{m}^{3}$ per year;

(2) Seepage from surface flow and floods:

Hydrological studies shows that over 52/07 million $\mathrm{m}^{3}$ of surface flow from high lands and 752/93 million $\mathrm{m}^{3}$ of internal flows from adjacent area and overall of 805 million $\mathrm{m}^{3}$ annually enter the alluvial zone and a part of these resources would feed the alluvial aquifer. This amount depends on several factors like average riverbed slope, water flow rate, and alluvial basin permeability ratio. On the basis of hydrological and geological studies, about $8 \%$ of surface flows in riverbeds and watercourses (ravines) enter the aquifer. So the volume of seepage water into the alluvial aquifer of the study area via surface and flood flows is 64/38 million $\mathrm{m}^{3}$ per year;

(3) Re-seepage of consumed water:

A part of utilized water from aquifer would re-enter to the soil after consumption whose amount is a function of type and method of water utilization. In drinking and industrial usage, this amount depends on sewage disposal (waste water disposal), soil permeability and the usage of absorption wells considered to be about $65 \%-80 \%$ and $50 \%-70 \%$. Seepage percentage from irrigation depends on genre and grading of the soil, type and the scale of planted area and irrigation system. In the approximate evaluation, this percentage for sprinkler irrigation is about $25 \%-30 \%, 15 \%$ in drip irrigation, in basin $30 \%-40 \%$ irrigation and the consumed water in furrow irrigation is about $25 \%-40 \%$. Considering the social structure of the region, consumption pattern, cultivation and common irrigation method, the amount of re-seepage water in the budget area is annually 18/41, $1 / 3,280 / 5$ and $300 / 1$ for each of the mentioned methods, respectively;

(4) Internal groundwater flow:

The volume of internal groundwater flows to aquifer is estimated using the same water transmissivity (T) maps and groundwater level maps. In this method, water transmissivity (T), alluvial sediments and groundwater level have been considered and then the volume of groundwater internal flow to aquifer has been estimated which is about 223/1 million $\mathrm{m}^{3}$ per 
year for this area.

\subsubsection{Discharging Factors}

The most important aquifer discharging factors are usage of groundwater resources, drainage, and evaporation from the aquifer surface and groundwater external flows which are estimated below:

(1) Usage of groundwater resources:

Discharging amount of groundwater resources in the budget area is about $788 / 49$ million $\mathrm{m}^{3}$ per year via wells, qantas and stings;

(2) Drainage:

The rivers of this area in its central and terminal path are acting like groundwater resources drainage. Estimation of the temporal variation of river discharge in the different pathway sections is essential for evaluation of drainage volume. In this study, according to amount of internal surface flows from the high lands, surface flows from precipitation on the plain, utilization of groundwater resources and external surface water from basin, it has been estimated to be about 45/0;

(3) External groundwater flows:

Based on calculation, the volume of External groundwater flows from alluvial aquifer in the study area is about $5 / 50$ million $\mathrm{m}^{3}$ per year;

(4) Evaporation from the aquifer surface:

This factor depends on groundwater level depth, soil type and texture, temperature of the environment, wind intensity, air relative humidity, and dense of water solute, most importantly, groundwater level depth [15]. This amount in the depth more than $5 \mathrm{~m}$ is too low and ignorable and in the depth less than $5 \mathrm{~m}$ could be estimated with White curve. According to the same depth map, groundwater level is less than $5 \mathrm{~m}$ in some parts of budget area. Also based on White curves, evaporation volume from aquifer surface is estimated to be about $28 / 76$ million $\mathrm{m}^{3}$.

\section{Results}

\subsection{Summary of Budget Calculations}

According to the amount of aquifer discharging and feeding factors, changing in storage volume is represented in Table 2. Considering this table, annual groundwater feeding volume in alluvial aquifer is about $861 / 1$ million $\mathrm{m}^{3}$ while annual discharging volume is about $867 / 76$ million $\mathrm{m}^{3}$.

\subsection{Changing in Storage Volume}

Considering the length of budget area of about $765 / 55 \mathrm{~km}^{2}$ and choosing average storage index about $3 \%$, changing rate of storage volume in annual average would be $-6 / 9$ million $\mathrm{m}^{3}$. This amount was estimated about $-6 / 66$ million $\mathrm{m}^{3}$ via budget calculation for aquifer. In an aquifer, groundwater budget comprises some special factors which were considered in calculation according to existence or nonexistence and storage volume changing could be determined based on the following equation:

Storage volume changing $=V$

Budget area $=A$

Storage index (without dimension) $=S$

Aquifer surface change in specific time $= \pm \Delta h$

$V=A S( \pm \Delta h)$

$7650.55 \times 0.03 \times(-0.29)=-6.66$

$Q_{\text {in }}+R_{p}+R_{r}+R_{w}-\left(Q_{\text {out }}+D+E+W\right)= \pm \Delta V$

$273.1+64.38+22.31+(1.3+18.41+280.5)-$ $(5.5+45+28.76+788.49)=-6.66$ where,

$Q_{\text {in: }}$ Ground water internal amount to aquifer;

$Q_{\text {out }}$ : External water amount from aquifer;

$R_{p}$ : Seepage water amount from precipitation which seeps directly to water table;

$R_{r}$ : Feeding amount from floods which deeply seeps to aquifer;

$R_{w}$ : Re-seepage water amount from irrigation and agriculture;

$D$ : Drainage from water table via diriment kinds of natural drainage;

$E$ : Evaporation from water table in the low depth surfaces of groundwater;

$W$ : Utilization of groundwater resources in natural or artificial ways (industrial re-seepage, drinking re-seepage, agricultural re-seepage). 
Table 2 Annual discharging and feeding storage factor in Marvdasht. The volume in million $\mathbf{m}^{3}$.

\begin{tabular}{lll}
\hline Area name & & Marvdasht \\
Storage volume changes & -6.66 \\
& Summation of feeding & 861.1 \\
& Water seepage in aquifer & 273.41 \\
& Runoff feeding & 64.38 \\
Feeding & Enteral from adjacent area & 0 \\
factors & Groundwater internal & 223.1 \\
& Industrial re-seepage & 1.3 \\
& Drinking re-seepage & 18.41 \\
& Agricultural re-seepage & 280.5 \\
& Discharge summation & 867.76 \\
Discharging & Groundwater external & 5.5 \\
factors & Aquifer drainage & 45 \\
& Evaporation from aquifer surface & 28.76 \\
& Groundwater discharge & 788.49 \\
\hline
\end{tabular}

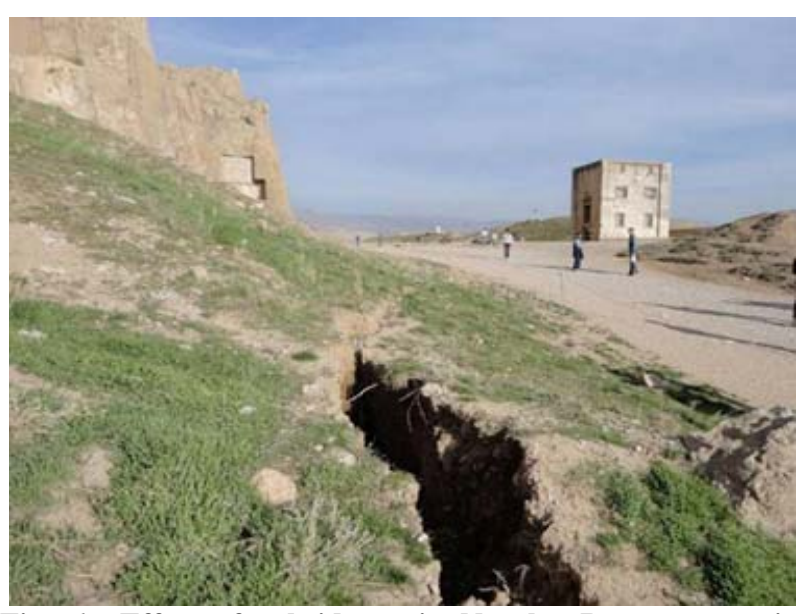

Fig. 6 Effect of subsidence in Naqsh-e-Rostam area in 2011.

\section{Discussion}

Ground subsidence phenomena is extended gradually and therefore, the resulted risks could not be like flooding and earthquake which suddenly occurs, but the destructive effects and consequences would be emerge gradually and comprises variation aspects like: heterogeneous changing in height and slope of rivers, waterways and water conveyor structures, disruption in groundwater resources utilization and sand production of wells, irrecoverable decreasing in total or a part of groundwater storage and therefore, complete wasting or decreasing in deposit useful porosity and also reduction of surface permeability which is followed by expansion of desert area, topographical changes and vastness of flooding plain [16] (Fig. 6). Subsidence is not happening specifically nowadays or in Iran or just in Fars, but this phenomenon is always affecting the plains, so that most of historical and ancient monument situated in plain area is buried as a result of steady subsidence of plain. Hence, this phenomena happens progressively and slowly as time goes by, lifetime duration of structure and human being is slower in comparison with subsidence rate, so the hazards are not that much remarkable.

But simultaneously, because of irregular utilization of water, dam construction and reduction in precipitation, groundwater discharge is more than aquifer feeding and therefore, groundwater level would be decreased and subsidence would happen [5]. While the aquifer is empty of water for a long time, the spaces which were full of water would gradually be closed and ground surface would be subsided. For this reason, subsidence could be seen in Fars and especially in the plain of granule sediments and Marvdasht plain is one of them, too. This phenomenon happens in the plain center and because of that, creation of cracks would be happen near the conjunction of mountains and plain area. In the northern part of Marvdasht plain and in the southern hillside of Rahmat mountain and Hossein mountain, these cracks could be seen nearly everywhere, all over Takht-e-Jamshid and Naqsh-e-Rostam beside plains. But ground subsidence is a phenomenon which occurs in alluvial sediments and plains and not in rock units, so the monuments which are located in bedrocks like Takht-e-Jamshid would remain safe. But Naqsh-e-Rostam site is in mountainside and surrounded by plains and farmlands, so it is not safe from it.

\section{Conclusions}

Existing natural factors like fault and earthquake in this area or any other faulted or seismic areas, also human factors and vibration resulted in intensive quakes, are not necessarily the creation factors of 
cracks and just subsidence phenomena is the main factor for the creation of these cracks in Naqsh-e-Rostam site. In this ancient area, because of irregular extraction on groundwater resources in natural and artificial ways like industrial, drinking or agricultural usage, changing rate of storage volume is negative and having negative budget rate shows reduction in groundwater level. This problem leads to creation of vast cracks in the area which begins from outside of the area and extends till miles. The effects of soil subsidence are serious and this site is exposed to the danger of more deterioration.

Reduction of groundwater level would be followed by some problems like drying of wells, decreasing in river discharge, reducing of water quality, rising cost of water extraction and pumping and ground subsidence.

The length and depth of some $10 \mathrm{~m}$ of these cracks in comparison with cracks and cleavages caused by faulting are not remarkable. So, subsidence just effective in ground surface and its ratio and hazards could be reduced with some provided methods.

To prevent the subsidence, some un-constructive works like filling illegal wells, prevention of over extraction, installation and utilization of intelligent water meter and electricity meter, informing the groundwater subscribers, elimination of drinking water from groundwater resources and drinking water supply from other sources like regional dams could reduce the erosion of subsidence and sink holes transitions and irrecoverable consequences.

Considering subsequence and survey using geophysical and radar, installation of sensitive instruments, geological engineering, geotechnical and hydrogeology studies are some of the proposed research in these regions.

\section{References}

[1] Pirniya, H. 1983. Ancient Iran. Tehran: Book Would.

[2] Shahbazi, A. S. 1994. "DARIUS iii. Darius the Great". Encyclopcedia Iranica. 7: 41-50. Accessed May 31, 2012. http://www.iranicaonline.org/articles/darius-iii.

[3] Heidemarie, K. 1992. Es kündet Dareios der König, vom Leben im persischen Großreich, Kulturgeschichte der antiken Welt LV, Mainz am Rhein: Verlag Philipp von Zabern. (English: It tells Darius the king, from life in the Persian empire)

[4] Taie, S. M., Fatehi, M. A., and Mirnia, S. K. 2011. "Investigation of the Effects of Artificial Groundwater Recharge on Temporal and Spatial Distribution of Hydrogeological Droughts using Piezometric State Index (Case Study: Garbaygan Plain, Fars Province)." Iran-Water Resources Research 3 (6): 61-9.

[5] Wang, B., and Yang, H. 2008. "Hydrological Issues in Regional Climate Modeling of the East Asian Summer Monsoon." Climate Dynamic 31: 477-90. doi: 10.1007/s00382-0080385-7.

[6] Poland, J. F. 1984. Guidebook to Studies of Land Subsidence due to Ground-Water Withdrawal. In studies and reports in hydrology, Unesco, Paris.

[7] Conklin, M. H., and Lui, F. 2008. Groundwater Contributions to Baseflow in the Merced River: Processes, Flow Paths, and Residence Times. PIER final project report.

[8] Timothy, H. D. 2006. "Space Geodesy: Subsidence and Flooding in New Orleans." Nature 441 (June): 587-8.

[9] James, W. B., and Michael, C. 2014. Land Subsidence from Groundwater Use in California. Full report of findings, lsce, borchers and carpenter.

[10] Conley, A., and Moote, M. 2003. "Evaluating Collaborative Natural Resource Management." Society \& Natural Resources: An International Journal 16: 371-386.

[11] Dunnicliff, J. 1993. Geotechnical Instrumentation for Monitoring Field Performance. Wiley-Interscience.

[12] Ferris, J. G., Knowles, D. B., Brown, R. H., and Stallman, R. W. 1962. Theory of Aquifer Tests. Water Supply Paper 1536-E. U.S. Geological Survey.

[13] Dhira, P. 1989. "Coming to Terms with Bangkok's Environmental Problems." Environment and Urbanization 1 (1): 31-9.

[14] Gregory, K. J., and Walling, D. E. 1976. Drainage Basin Form and Process: A Geomorphological Approach. Hodder Arnold: New Edition.

[15] Savvaidis, P., Ifadis, I., and Doukas, I. 2004. Monitoring and Analysis of Ground Subsidence due to Water Pumping in the Area of Thessaloniki, Hellas. Athens: FIG Working Week.

[16] Waltham, A. C. 1989. Ground and Subsidence. New York: Chapman and Hall. 